\title{
THE LINKS BETWEEN TRADE POLICY AND TOTAL FACTOR PRODUCTIVITY IN SOUTH AFRICA'S MANUFACTURING SECTOR ${ }^{1}$
}

\author{
C. HARMSE* AND C.A. ABUKA*
}

\begin{abstract}
This paper reconfirms the important links that exist between manufacturing productivity, trade orientation, industry specific characteristics and some macroeconomic variables. The dynamic GMM estimator used in the analysis shows that apart from being affected by trade measures, total factor productivity is strongly persistent. In addition, the evolution of the real exchange rate and inflation exert important effects on manufacturing productivity. Most importantly, the dynamic error component specification appears to be more efficient in modelling the effects on manufacturing productivity of policy change than the static approach.
\end{abstract}

\section{INTRODUCTION}

While some literature on trade policy and market structure provides several mechanisms through which trade expansion may boost industry productivity, a significant amount of theoretical literature still delivers disparate predictions regarding the impact of trade on productivity (Pavcnick, 2002:2). Hence empirical evidence is still vital to inform the debate. This paper addresses a fundamental issue regarding the mechanisms through which increased trade affects industrial productivity. A South African panel data set is used to provide a comprehensive picture of the macroeconomic and structural determinants of manufacturing productivity. This data set combines the advantages of macroeconomic time series and microeconomic cross sections. South Africa provides a good environment in which to investigate these issues because not only has trade policy over the last two and a half decades exhibited significant variation, there has also been explicit heterogeneity across industrial sectors in response to trade expansion (Fedderke, 2001 a and b; TIPS; 2001, Roberts, 2000; Jonsson and Subramanian, 2000).

To obtain productivity growth a production function is estimated in which industry productivity is modelled as an unobservable industry specific effect. This approach generates sector specific as well as time varying productivity measures. The analysis then searches for the channels through which measures of trade orientation interact with industrial characteristics and the macroeconomic environment to determine productivity growth. The problem resident in previous attempts is that they were obsessed with measuring the impact on productivity of a single variable, namely trade policy (Fernandez, 2002:20). This paper argues that the more interesting angle for investigation is to study the channels through which trade affects productivity using an identical country panel.

This paper provides empirical estimates of the determinants of total factor

\footnotetext{
${ }^{1}$ The comments and suggestions of several anonymous referees are acknowledged. * Professor, Economics Department, University of Pretoria, Email: chris.harmse@up.ac.za $\mathrm{PhD}$ (Economics) Student, Economics Department, University of Pretoria;. Email: cabuka@bou.or.ug and ca_abuka@yahoo.co.uk
} 
productivity in South Africa's manufacturing sector. It begins with a discussion of the literature relevant to the analysis of the productivity and trade linkages in sections 2 and 3. The empirical specification issues are presented in sections 4 and 5. The data investigated and the results are provided in section 6 , and concluding comments follow in section 7 .

\section{TRADE AND MANUFACTURING PRODUCTIVITY}

If there are benefits to a country's manufacturing sector that arise from trade then these benefits should result from two sources. The first source is from greater efficiency in production through increased competition and specialisation. The second source is from the opportunities that arise to exploit economies of scale in a larger market. Access to a larger market should encourage larger production runs in industries and so reduce average costs. Trade expansion should therefore, permit firms to increase in size and engage in more plant specialisation. In an environment of increased trade, consumers' demand for variety will be satisfied through imports. Access to the world market also means that more products can be produced profitably and this should generate gains from increased product diversity and improve consumer welfare (Petersson, 2002:241).

Proponents of trade liberalisation aim to promote productivity gains by exposing industries to fiercer international competition and facilitating access to the international market. They argue that establishments that face foreign competition are forced to adapt. In particular, plants are encouraged to produce closer to the production possibility frontier whilst the frontier itself will move out faster. Most importantly, evidence indicates that manufacturing concerns exposed to trade pay higher wages, operate at a higher scale, produce with more capital and achieve higher productivity levels (Van Biesebroeck, 2003). Productivity growth seems to be directly associated with production of tradable goods. This implies that the benefits from foreign activities are likely to be higher in two areas; firstly, in places where the domestic market is small and foreign sales are a prerequisite to fully exploit scale economies and, secondly, where production technology lags best practice, providing ample scope for productivity improvements through imitation and adoption of foreign technology. Literature suggests a number of mechanisms or channels through which trade liberalisation affects manufacturing productivity (Fernandez, 2003:3; Van Biesbroek, 2003; Pavcnik, 2000:2, and Muendler, 2002:2,). These channels include:

\section{(a) Foreign Input Push}

The first channel is the foreign input push. Easier access to equipment and intermediates may allow a foreign input push at the firm level. This is because high quality equipment and intermediate goods allow industries to adopt new production methods. The use of these inputs raises efficiency. This is because the efficiency of foreign equipment and intermediate inputs is higher than the efficiency of domestic inputs (Feenstra, Markusen and Zeile, 1992 and Fernandez, 2003). In the same vein, studies of competitive effects of increased import penetration such as Krishna and Mitra (1998) and Tybout and Wesbrook (1995) demonstrate that increased competition from imports in fact lowers the price-cost margin.

(b) Competitive Push and Elimination of X-inefficiency.

The second channel is via competitive push and elimination of $X$-inefficiency. Firms 
are said to respond strongly to increased competitive pressure and raise their efficiency. The turnover and the exit of the less productive firms contribute positively to productivity change. Since the removal of import barriers increases competition on the product market side, foreign imports constitute a competitive push on individual firms. Theory suggests that managers remove agency problems and introduce innovative processes under fierce competition (Pavcnik, 2000:37). In particular, the elimination of X-inefficiency or slack occurs as imports expand, and the ensuing competitive pressure results in higher productivity as firms use inputs more efficiently (Fernandez, 2003:3 and Fernandez, 2002:4).

By reducing protection trade liberalisation lowers domestic prices, forcing high cost producers to exit the market. To compete against international producers domestic firms must adopt newer and more efficient technology or use the same technology with less $\mathrm{x}$ inefficiency in order to reduce costs (Tybout et al, 1991). This could result in a reallocation of output from less efficient to more efficient producers. These gains, however, result only if irreversibility of investment in capital equipment does not stop the exit of less productive plants.

\section{(c) Competitive Elimination}

The third channel is through competitive elimination. Competition in the product market may also induce more exists and cause a competitive elimination of inefficient producers (Muendler, 2002:28). Increased competitive pressure causes the least efficient firms to shut down and enables the surviving, competitive plants to increase market share. The increase in market share is what raises productivity. In Chile aggregate productivity improvements in a number of industries were found to stem from reshuffling resources from less to more efficient firms as a result of trade expansion (Pavcnik, 2000:3). When trade barriers fall, competitive elimination of least efficient firms is said to strike more fiercely. Estimates from turnover probabilities confirm that the likelihood of survival drops markedly when trade barriers fall and that low efficiency firms go out of business more frequently (Muendler, 2002:4).

Pavcnik (2000:6) finds that productivity improvements in Chile were indeed related to trade liberalisation and that competition forced plants in sectors that used to be shielded to restructure. Most importantly, exiting plants were on average less productive than plants that continued to produce. Plant exit contributes to a reshuffling of resources within the economy and a reallocation of market shares as well as resources from less to more efficient producers. This acts as an important channel for productivity improvements.

(d) Higher Incentives for Technological Innovation

The fourth channel is through higher incentives for technological innovation. Trade can spur innovation by enhancing industrial learning since it facilitates international exchange of technical information and can improve the efficiency of global research efforts in different countries. One of the links between international trade and productivity is through technical knowledge spillovers (Grossman and Helpman, 1991). International trade boosts research by transmitting information, increasing competition and entrepreneurial effort and expanding the size of the market for innovative firms. Trade encourages modern technology, increases demand for skilled labour and promotes learning by doing. Trade expansion may contribute to the exchange of ideas, adoption of technological knowledge and faster productivity growth. 
(e) Economies of Scale.

Trade liberalisation exposes domestic producers to foreign competition, reduces their market power and may force them to expand output and move down the average cost curve, resulting in the exploitation of economies of scale.

\section{IS THERE A NEGATIVE ASSOCIATION BETWEEN TRADE AND PRODUCTIVITY?}

There are arguments suggesting that increased foreign competition may be injurious to domestic industries if it leads to a closure of factories (Van Biesbroek, 2003). Indeed, Rodrik (1991) finds that lower protection or higher import competition reduces a firm's investment in productivity enhancing technological upgrading. This is especially the case when the incentive to invest depends on the firm's output or market share - yet trade liberalisation reduces that market share. Deraniyagala and Fine, (2000:98) also argue that the magnitude of gains from liberalisation could be fairly low. If trade reduces the domestic market shares of unshielded domestic producers without expanding their international sales, their incentives to invest in improved technology will decrease as protection ceases. This effect reduces the benefits of tariff reductions that are supposed to lower the relative prices of imported capital goods and ease access to foreign technology for domestic firms (Pavcnik, 2000:37). It is also argued that liberalisation does not facilitate acquisition of better technology by domestic plants because acquisition is dependent on the flexibility of the domestic labour force. Muendler (2002:1) finds that foreign technology adoption may be relatively unimportant. This is because the efficiency difference between foreign and domestic inputs has only a minor impact on productivity in some cases. The explanation for the minor impact lie in the fact that foreign technology adoption takes time due to delays in learning, difficulties with

factor complementarities and differences in production arrangements. Even in the context of economies of scale, theoretical trade literature offers conflicting predictions about the evolution of plant productivity following a liberalisation episode, especially in cases where imperfect competition is present. Gains from economies of scale in developing countries may also be unlikely because increasing returns to scale are usually associated with import competing industries, whose output is likely to contract due to intensified foreign competition (Pavcnik, 2000:2)

\section{APPROACHES TO THE STUDY OF TRADE AND PRODUCTIVITY}

There are three main approaches that have been applied to studying the relationship between trade and productivity in the literature. These include:

(a) The Macro-Level Approach.

The macro- level approach undertakes cross-country comparisons using growth regressions associating output growth with an aggregate measure of trade openness. The findings from these studies suggest that open economies tend to grow faster (Sachs and Warner, 1995). The difficulties of using measures of outward policy orientation across countries and over time have been pointed out (e.g. in Rodrik and Rodriquez, 2001). In particular, aggregate measures of openness fail to capture the differential incentives provided by trade protection to different industries. They also suffer from endogeneity, and a number of specification problems. The results of these studies are 
sensitive to the sample of countries used as well as the time periods analysed, while the conclusions depend on whether the study employed cross-section or panel data (Harrison, 1996). More so, many country specific variables that are of relevance to productivity could be correlated with other regressors or may in fact be unobservable. Such variables include country policies or historical factors. To the extent that these do not vary over time, fixed effect estimates could in principle be used to deal with the problem but this is limited by two factors. Firstly, many of the variables hypothesised to cause productivity changes are also time invariant or may change only very slowly over time and may thus not be easily distinguished from country level fixed effects. Secondly, cross-country time series data that are comparable are still relatively rare, especially in African countries. It is therefore important to assess the extent to which results from cross-country analysis hold up to more rigorous scrutiny than is possible within individual countries. Individual country data has the advantage of being available at a lower level of aggregation and allows for a much more precise definition of the variables of interest (Deininger, 2003).

(b) The Industry-Level Approach.

The industry-level approach attempts to circumvent the problems that plague crosscountry macro level studies by considering cross-industry regressions in the spirit of Solow's residual total factor productivity growth on trade policy variables (Kim, 2000, and Lee, 1995), or on demand growth due to export expansion and import substitution (Nishimizu and Robinson, 1983). The main weakness pointed out in these studies is that a single productivity measure could ignore cross-plant heterogeneity, which is a stylised fact in many countries and may be useful in investigating the impact of trade on productivity. Industry-level studies have also been criticised by Muendler (2002) for being unable to unmask the underlying microeconomic processes as seen in Kim (2000).

(c) The Micro- Level Approach

The micro-level approach on the other hand is a microeconomic branch that uses longitudinal data to trace the effects of trade exposure on firms or plants in select countries. This approach uses regressions derived from two main sources. In the first approach, firm output growth generated in a Solow framework is regressed on an indicator variable over the period of trade reform (Krishna and Mitra, 1998). The second is based on plant TFP measures in relation to trade policy orientation in the industry (Pavcnik, 2000 and Fernandez 2003). These two approaches were able to identify the effect of trade reform in Chile and Colombia respectively. The second approach that is based on plant TFP measures is not without criticism because the indicator variable for the trade reform period cannot isolate the corresponding productivity gains. The productivity gains will also capture contemporaneous macroeconomic shocks. Most importantly, this indicator could ignore the variation in productivity across industries.

\section{EMPIRICAL ISSUES IN MEASURING PRODUCTIVILY GROWTH}

The production function approach is the most popular method used to capture productivity and then link its growth to foreign trade variables, protection measures, industry specific characteristics and macroeconomic shocks. Two types of functions are employed. The first is an aggregate value added function while the second is a gross 
output function. The analysis usually starts by assuming plant /' $S$ technology at time $t$ as being described by a production function, specifying gross output as:

$$
y_{i t}=\beta_{0}+\beta_{n} n_{i t}+\beta_{m} m_{i t}+\beta_{k} k_{i t}+\varepsilon_{i t}
$$

The industry specific effect is defined as:

$$
\varepsilon_{i t}=w_{i t}+u_{i t}
$$

where

$n_{i t}$ is labour, $m_{i t}$ is intermediate raw material inputs, $k_{i t}$ is capital used in

industry $i$ at time $t$, and $\varepsilon_{i t}$ is the industry specific efficiency that is composed of two

terms, $w_{i t}$ which is known by the plant but not by the researcher and $\boldsymbol{u}_{i}$, which is the

unexpected productivity shock not known to both the plant and the researcher.

The industry productivity measure relies on the difference between an industry's actual output and predicted output. It is important to obtain consistent estimates of the coefficients in the production function. It is known that a plant's private knowledge of its productivity $w_{i t}$ affects it's decisions about its choice of hiring labour, purchasing

materials and investing in new capital. More productive industries are more likely to hire more workers and invest in capital due to profitability. However, the effect of the plant's knowledge is unobserved to the econometrician. This information asymmetry introduces simultaneity bias (Fernandez 2003:5, Pavcnik, 2000:8 and Olley and Pakes, 1996).

Simultaneity bias arises because an industry's private knowledge of its productivity affects its choice of inputs. The use of ordinary least squares for production function estimation assumes that regressors such as labour are treated as exogenous variables. Yet input choices could indeed be endogenous. Since input choices and productivity are correlated, OLS estimates suffer from simultaneity bias (Fernandez 2003:5). OLS estimation of a production function may lead to estimates of the input coefficients that are higher than their true values. Four main mechanisms are employed to control the simultaneity problem.

The first mechanism is to impose a normal distribution on the unobserved heterogeneity and assume that the industry specific efficiency is uncorrelated with the industry's choice of inputs, and to use maximum likelihood estimation (Tybout et al, 1991). The second mechanism is to assume that the unobserved industry specific

efficiency $w_{i}$ is time invariant and to estimate the production function using a fixed effects model of the form:

$$
y_{i t}=\beta_{0}+\beta_{n} n_{i t}+\beta_{m} m_{i t}+\beta_{k} k_{i t}+w_{i}+u_{i t}
$$

The fixed effects model partially solves the simultaneity problem insofar as it removes the effects of the time-invariant plant's productivity component (Pavcnik, 2000:8). However, during times of large structural adjustments such as trade liberalisation, the assumption of unchanging productivity is not tenable and the fixed effects methodology could generate biased estimates of the input coefficients. Moreover, if one is interested in how industry efficiency evolves over time in response to a change in trade regime, the assumption that plant productivity is constant over time does not help in tackling the problem.

The third mechanism is to use an industry specific and time varying efficiency measure that can be captured as a quadratic function of time (Liu and Tybout (1996). In 
this case the production function is specified as:

$$
\begin{aligned}
& y_{i t}=\beta_{0}+\beta_{n} n_{i t}+\beta_{m} m_{i t}+\beta_{k} k_{i t}+w_{i}+u_{i t} \\
& w_{i t}=\alpha_{1 i}+\alpha_{2 i} t+\alpha_{3 i} t^{2}
\end{aligned}
$$

In this framework the production function is first estimated by fixed effects to obtain the input coefficient vector $\beta$. The residuals are then calculated by subtracting the actual from the predicted values of output and for each industry $i$ this residual measure is regressed on a constant, time and time squared. A productivity measure is then constructed using estimates of the coefficients from the last regression. The approach that uses a residual measure that is regressed on a constant, time and time squared, improves on the fixed effects methodology but is punitive as many degrees of freedom are lost in the estimation process.

While the traditional approach is anchored in the use of instrumental variables or within estimators to control simultaneity, an alternative approach was suggested by Olley and Pakes (1996) and modified by Levinsohn and Petrin (2001). This approach has found numerous applications, most notably by Pavcnik (2000:10), Fernandez (2003:12) and Driemeier, Iarossi and Sokoloff (2002:38). In the Olley-Pakes framework labour and materials were assumed to be freely variable while capital is the state variable, affected by the distribution of the productivity shock. The observed firm decision in this case will be a function of productivity of the firm and inverting such a function allows for the anticipated but unobserved productivity shock to be controlled for using the observed variables. Investment is used to model the anticipated productivity shock. In this case, the inputs are divided into freely variable $n_{i}$ and $m_{i}$ while $k_{i}$ is the state variable. The productivity shock $w_{i t}$ is also a state variable and impacts on the decision rules of industries while $\mu_{i t}$ has no impact on firms' decisions.

It is also an i.i.d component. Under perfect competition input and output prices are common across firms making it possible to assume invertibility and write investment as

a function of two state variables, e.g. $i_{i t}=i\left(w_{i t}, k_{i t}\right)$. This can be inverted to yield

$$
w_{i t}=i\left(i_{i t}, k_{i t}\right)
$$

Foulation (1) under the monotonicitv assumption can then be written as:

$y_{i t}=\beta_{n} n_{i t}+\beta_{m} m_{i t}+\phi_{i t}\left(i_{i t}, k_{i t}\right)+u_{i t}$

where

$\phi_{i t}\left(i_{i t}, k_{i t}\right)=\beta_{0}+\beta_{k} k_{i t}+w_{i t}\left(i_{i t}, k_{i t}\right)$

Different measures of logarithmic productivity can be generated using two estimation methods depending on whether a TFP measure or a shock invariant productivity measure is considered. From equation (1) our TFP measure is given as:

$$
w_{i t}+\mu_{i t}=y_{i t}-\beta_{n} n_{i t}-\beta_{m} m_{i t}-\beta_{k} k_{i t}=p r_{i t}
$$

The no shock productivity measure that excludes the component of the shock to output that is uncorrelated with inputs is derived following the techniques used by Olley and Pakes (1996). A polynomial in $i_{i t}$ and $k_{i t}$ in the regression of output on the variable inputs is used to model the qualified variation in productivity. A second order polynomial in investment and capital can be used to provide an industry specific and 
time varying productivity measure in the form:

$$
w_{i t}=p r_{i t}-\delta_{k} k_{i t}-\delta_{i} i_{i t}-\tau_{1 t} i^{2}-\tau_{2 t} k^{2}-\tau_{3 t} k_{i t} i_{i t}
$$

The advantage is that while this approach requires a few restrictive assumptions, it does not need a specific functional form; yet it provides a tractable solution to the simultaneity problem (Driemeier, Iarossi and Sokoloff, 2002:38).

\section{ECONOMETRIC SPECIFICATION}

The estimation proceeds in two steps. Firstly, we obtain time-varying and industry specific measures of industry productivity. Secondly, the channels through which manufacturing productivity interacts with foreign trade variables, protection measures, industry specific characteristics and the macroeconomic environment, are modelled in a regression framework. This approach essentially relies on measures that exhibit I significant variation across industries and over_time. An approach that incorporates industry specific characteristics, trade and policy measures are superior to previous attempts that relied on a single change in trade regime. In the dynamic specification, the potential endogeneity of trade policy measures is considered by employing lagged trade measures and by controlling for industry fixed characteristics (Fernandez 2002; Tybout and Westbrook, 1995). Initially a productivity measure is derived following equation (8) above as:

$$
t f p_{i t}=y_{i t}-\beta_{n} n_{i t}-\beta_{m} m_{i t}-\beta_{k} k_{i t}
$$

Two models for the determinants of total factor productivity can then be specified for the manufacturing sector. Equation (11) provides the static model, while equation (12) is the dynamic specification. Dynamics are introduced in equation (12) by considering the impact of lagged productivity.

$$
\begin{aligned}
& t f p_{i t}=\beta_{0}+\left(\beta_{1}\right)^{\prime} T P_{i t}+\left(\beta_{2}\right)^{\prime} X_{i t}+\left(\beta_{3}\right)^{\prime} M_{i t}+\varepsilon_{i t} \\
& t f p_{i t}=\beta_{0}+t f p_{i t-1}+\left(\beta_{1}\right) T P_{i t}+\left(\beta_{2}\right) X_{i t}+\left(\beta_{3}\right) M_{i t}+\varepsilon_{i t}
\end{aligned}
$$

Where TP is a trade policy measure, $\mathrm{X}$ consists of industry level characteristics and $\mathrm{M}$ captures the role of macroeconomic factors; while the two-way error components are

$\varepsilon_{i t}=\mu_{i}+\lambda_{t}+v_{i t}$

$i=$ the standard industrial classification for the 28 sectors from 301 to 392 and

$t=1980,1981, \ldots ., 2002$. The symbol $\mu_{i}$ denotes a product specific effect while

$\lambda_{t}$ denotes a time specific effect and $v_{i t}$ is the remainder of the white noise stochastic error

term. Product specific effects are time invariant characteristics of the different products such as entrepreneurial and managerial skills in different industries, attributes embedded in products, language and business culture as well as political economy issues. Product specific dummies capture these, as data for them is unavailable. Time specific effects capture the effects of policy interventions, trade policy shifts, sanctions, the General Export Incentive Scheme (GEIS), membership in the WTO and changes in productivity due to innovation and the role of the post-apartheid government since 1994. Again since data on these key changes is unavailable, their effects are captured using time specific dummies. For simplicity we assume that product specific and time specific effects are fixed parameters to be estimated and all the remainder of the 
disturbances are stochastic, independent and identically distributed.

\section{ECONOMETRIC RESULTS}

(a) The Data and Variables

In this study productivity analysis is based on industry level panel data from the South African manufacturing database provided by Statistics South Africa (STATSA), Trade and Industry Policy Strategies (TIPS) and the South African Reserve Bank. For each industry, data is available on production and sales revenues, input use (labour categories and raw materials), investment, exports and imports at the ISIC industry code. Final output refers to goods produced by industry used or consumed by individuals, households and firms and not processed further or resold. Materials refer to the value of materials input in millions of Rand. Employment figures indicate the number of paid employees and include casual and seasonal workers. Employment consists of three main categories, namely highly skilled, skilled and semi-and unskilled labour. Industry level capital stock is obtained at constant 1995 prices while gross mark-up of an industry is the net operating surplus of that industry as a percentage of total intermediate inputs plus labour remuneration less all net indirect taxes. Intermediate imports are imports of goods and services produced elsewhere in the world but used as inputs in the production process in industries.

The export-output ratio is total exports divided by the gross total output value of domestic industries while the import-domestic demand ratio or import penetration is equal to total imports divided by total domestic demand. Skill intensity is the ratio of the number of skilled employees to the total number of employees in an industry. Industry level machinery and equipment expenditure is measured in constant 1995 prices and is used as a proxy for research and development. The terms of trade index takes 1995 as the base year and is obtained from the South African Reserve Bank while the percentage utilisation of production capacity defines capacity utilisation such that 100 per cent would refer to full capacity utilisation. Market size is the domestic sales value of industries to the total industrial output. Tariffs are calculated as the sum of customs payments divided by the value of imports. The real effective exchange rate of

the Rand (RER) with base year 1995 is identified as series KBP5036J in the Reserve Bank Quarterly Bulletin Time Series. Inflation is defined as the change in the consumer price index published by statistics South Africa. Table 1 contains the descriptive statistics of the key variables used in the estimation process.

Table 1 shows a degree of heterogeneity in some of the key variables. For example, the mean export share is 13.4 per cent, covering a range marginally in excess of 0.2 per cent up to a maximum of 67 per cent. Import penetration also exhibits heterogeneity with a mean penetration rate of 20.4 per cent, a minimum of 0.5 per cent and a maximum of 89 per cent. Industry capacity utilisation is relatively more stable. The mean capacity utilisation rate is 82 per cent, the maximum recorded is 97 per cent with a standard deviation of 6.2.

In the next step the analysis proceeds to estimating the static and dynamic equations of the determinants of total factor productivity in manufacturing. The results of the estimation are presented in Tables 2 and 3 below. 
Table 1. Descriptive Statistics for TFP Variables

\begin{tabular}{llllll}
\hline Variable & Definition & Mean & $\begin{array}{l}\text { Standard } \\
\text { deviation }\end{array}$ & Minimum & Maximum \\
EX & Export share & 13.40 & 13.79 & 0.23 & 66.95 \\
MZ & Import penetration & 20.35 & 17.47 & 0.53 & 89.07 \\
GM & Gross mark up & 18.54 & 20.63 & 0.69 & 202.77 \\
IM & Intemediate Imports & 11.24 & 7.44 & 0.83 & 83.05 \\
MS & Market share & 3.57 & 6.19 & 0.06 & 14.71 \\
TARIFF & Customs duties paid & 6.84 & 6.48 & 9.13 & 98.96 \\
RAD & Machinery expenditure & 70.31 & 16.99 & 59.8 & 129.3 \\
RER & Real exchange rate & 97.13 & 15.01 & 9.58 & 121.83 \\
SKILL & Skill intensity & 36.23 & 12.85 & 93.56 & 157.80 \\
TOT & Terms of trade & 101.28 & 6.27 & 67.33 \\
CPI & Consumer price index & 73.83 & 45.41 & 62.3 & \\
CAP & Capacity utilisation & 82.03 & 6.16 & & \\
Memorandum items & Number of industries & 28 & & & \\
I & Number of periods & 23 & & & \\
T & Number of observations & 644 & & & \\
N &
\end{tabular}

Sources: Computed from http//www.tips.org.za, http//www.statssa.gov.za, http//www.resbank.co.za,

\section{(b) Static Panel Estimates of the Determinants of Total Factor Productivity}

The expectation is that increased export shares should associate positively with total factor productivity. Import penetration ratios are expected to affect productivity positively if industries lower costs and become more efficient when import competition increases (Fernandez, 2003). However, if imports are endogenous with respect to domestic industries' productivity, a negative correlation may arise. A negative correlation arises because some import competing industrial sectors attract imports by being relatively less productive. The reduction in tariffs is also expected to impact positively on industrial productivity growth.

Furthermore, an increase in intermediate imports, increased skill intensity and growth in investment in machinery and equipment should impact positively on productivity. However, an appreciation in the real exchange rate or an increase in inflation should associate negatively with industry productivity performance. An increase in capacity utilisation should be positively related to manufacturing productivity ${ }^{1}$.

In the light of the expectations indicated above, Table 2 below presents the results of the random effects maximum likelihood regression. The results show that the export: output ratio had a positive and statistically significant relationship with total factor productivity. A one per cent increases in the export: output ratio would increase total factor productivity by 0.78 per cent. Miller and Uphadhay (2000) reach a similar conclusion, namely, more openness associates with high total factor productivity using an aggregate sample that included African countries. Gunnar and Subramanian (2000), employing aggregate time series of South African manufacturing data, find a 10 percentage point increase in openness associated with an increase in total factor productivity by 5 per cent in the long run.

The increase in import penetration had a significant negative association with the level of total factor productivity, suggesting that imports may be endogenous with respect to productivity in some domestic industries. A one per cent increase in the

\footnotetext{
${ }^{1}$ TFP growth is likely to be sensitive to the business cycle because capital and labour inputs are difficult to adjust in the short-run, output fluctuations will be related to fluctuations in import and export shares. To deal with this simultaneity problem capacity utilisation is used as a dependent variable (Gunnar and Subramanian, 2000).
} 
import penetration ratio would decrease total factor productivity by 0.63 per cent. It seems imports are being attracted to manufacturing sectors with relatively less productive industries. In contrast Bjurek and Durevall (1998) using Zimbabwean manufacturing industry data report that an increase by one percentage point in imports raised total factor productivity by 0.2 percentage points.

Table 2. Estimating TFP determinants by maximum likelihood regression

\begin{tabular}{|c|c|c|c|c|c|c|}
\hline \multicolumn{7}{|c|}{ Random effects ML regression: Dependent variable total factor productivity } \\
\hline Variable & Coefficient. & Std. Err. & Z & $\mathrm{P}>|z|$ & \multicolumn{2}{|c|}{ [95\% Conf. Interval] } \\
\hline Export: output ratio & 0.7751 & 0.1887 & 4.11 & 0.000 & 0.4052 & 1.1451 \\
\hline Import penetration ratio & -0.6257 & 0.2105 & -2.97 & 0.003 & -1.0384 & -0.2132 \\
\hline Market size & -0.2639 & 0.0941 & -2.80 & 0.005 & -0.4485 & -0.0794 \\
\hline Machinety expenditure & 0.4659 & 0.1938 & 2.40 & 0.016 & 0.0859 & 0.0846 \\
\hline Intermediate imports & 1.1152 & 0.2014 & 5.53 & 0.000 & 0.7203 & 1.5101 \\
\hline Tariff & 0.0697 & 0.0169 & 4.13 & 0.000 & 0.0366 & 0.1028 \\
\hline Capacity utilisation & 0.1677 & 0.1065 & 1.57 & 0.115 & -0.0410 & 0.3764 \\
\hline Rand teal exchange rate & -0.0579 & 0.2179 & -0.27 & 0.790 & -0.4851 & 0.3691 \\
\hline Inflation & -0.8011 & 1.0747 & -0.75 & 0.456 & -2.9075 & 1.3052 \\
\hline Export output ratio $X_{\text {market share }}$ & 0.0579 & 0.0114 & 5.08 & 0.000 & 0.0355 & 0.0802 \\
\hline Export output ratio $X_{\text {real exchange rate }}$ & -0.1254 & 0.0363 & -3.45 & 0.001 & -0.1967 & -0.0542 \\
\hline Export output ratio $X_{\text {inflation }}$ & -0.7002 & 0.1725 & -4.06 & 0.000 & -1.0384 & -0.3620 \\
\hline Import penetration ratio $X_{\text {market share }}$ & -0.0122 & 0.0154 & -0.79 & 0.428 & -0.0423 & 0.0179 \\
\hline Import penetration ratio $X_{\text {real exchange rate }}$ & 0.0937 & 0.0438 & 2.14 & 0.032 & 0.0078 & 0.1795 \\
\hline Import penetration ratio $X_{\text {tariff }}$ & -0.0267 & 0.0065 & -4.09 & 0.000 & -0.0396 & -0.0139 \\
\hline Import penetration ratio $X_{\text {inflation }}$ & 0.0403 & 0.1939 & 2.08 & 0.038 & 0.0232 & 0.7832 \\
\hline Machinety expenditure $X_{\text {market share }}$ & -0.0134 & 0.0128 & -1.05 & 0.295 & -0.0385 & 0.0117 \\
\hline Machinery expenditure $X$ real exchange rate & -0.1126 & 0.0431 & -2.61 & 0.009 & -0.1972 & -0.0281 \\
\hline Machinety expenditure $X_{\text {inflation }}$ & 0.0276 & 0.1969 & 0.14 & 0.889 & -0.3585 & 0.4137 \\
\hline Intermediate imports $X_{\text {market share }}$ & 0.0449 & 0.0146 & 3.08 & 0.002 & 0.0163 & 0.0735 \\
\hline Intermediate imports $X_{\text {real exchange rate }}$ & -0.2331 & 0.0451 & -5.17 & 0.000 & -0.3215 & -0.1447 \\
\hline Intermediate imports $X_{\text {inflation }}$ & -0.1791 & 0.1816 & -0.99 & 0.324 & -0.5349 & 0.1767 \\
\hline Export output ratio $X_{\text {skill intensity }}$ & -0.0616 & 0.0225 & -2.74 & 0.006 & -0.1056 & -0.0175 \\
\hline Import penetration tatio ${ }_{\text {skill intensity }}$ & 0.0458 & 0.0216 & 2.13 & 0.034 & 0.0036 & 0.0881 \\
\hline Constant & -0.1462 & 1.0658 & -0.14 & 0.891 & -2.2351 & 1.942 \\
\hline /sigma_u & 0.0708 & 0.0149 & 4.74 & 0.000 & 0.0415 & 0.1001 \\
\hline /sigma_e & 0.1228 & 0.0037 & 32.78 & 0.000 & 0.1155 & 0.1301 \\
\hline Rho $=$ & 0.2496 & 0.0816 & & & 0.1190 & 0.4317 \\
\hline Group variable & sector & & Numb & & 589 & \\
\hline Time variable & year & & Numb & roups & 28 & \\
\hline Log Likelihood & 370.538 & & LR chi & & 243.44 & \\
\hline Random effects & gaussian & & Chibar & & 23.71 & \\
\hline Prob $>$ chi $^{2}$ & 0.0000 & & Prob $>$ & & 0.000 & \\
\hline
\end{tabular}

Source: Estimation results by the authors'

Increases in market size had a negative impact on total factor productivity, indicating that productivity gains were higher for smaller industrial sectors. A one per cent increase in the market share would decrease total factor productivity by 0.26 per cent. Trade liberalisation however contributes only marginal towards skills improvement. A one per cent increase in import penetration will only leads to a 0.045 per cent increase in skills intensity. Once again it benefits small industrial sectors as large skills adjustments don't have to be implemented immediately.

Investment in equipment and machinery is used to proxy technology acquisition: 
since South African industries do not engage in substantial research and development activity, the bulk of research and development is likely to be embodied in capital equipment. As expected this variable had a positive and significant association with productivity. A one per cent increase in the machinery and equipment expenditure would increase total factor productivity by 0.48 per cent. A similar finding is reported in Gunnar and Subramanian (2000) where a 10 percentage point increase in the share of machinery and equipment investment was associated with an increase in total factor productivity by 3 per cent. The use of intermediate imports also represents an interaction between South African firms and the outside world. An increased use of intermediates had a positive and significant impact on productivity. A one percent increase in the intermediates would increase total factor productivity by 1.12 per cent.

The tariff variable ${ }^{2}$ was significant but wrongly signed, suggesting that a one per cent increase in the tariffs would increase total factor productivity by 0.07 per cent. This is counter to the findings of Gunnar and Subramanian (2000) in which it was indicated that the annual growth rate in total factor productivity was nearly 3 percentage points higher in sectors where tariffs were reduced by 10 per cent compared with sectors where tariffs were unchanged. In the same thrust, Brazilian data suggests that the effect of nominal tariffs can be identified after controlling for endogeneity of nominal tariffs. The estimated coefficient for tariffs in the productivity equation was negative, even when a measure of tariffs on inputs was added to the productivity equation; the associated coefficient on tariffs on inputs remained negative. The key message is that there is a huge degree of heterogeneity of responses to trade liberalisation and that the effect of tariff reductions depends heavily on the observed and unobserved characteristics of the industries (Schor, 2004).

In the static model, capacity utilisation had an insignificant impact on productivity performance. This is contrary to the findings of Gunnar and Subramanian (2000), though the impact of capacity utilisation in capturing business cycle effects is followed up in the dynamic model presented in Table 4.

Current levels of inflation and the real exchange rate had an insignificant impact on productivity. However, a real exchange rate depreciation should increase the demand for and profitability of traded industries' output. Therefore, real exchange rate changes that stimulate exports and limit imports associate with higher total factor productivity. In Zimbabwe, Bjurek and Durevall (1998) report that increases in inflation reduced manufacturing total factor productivity, explaining the empirical regularity between higher inflation and lower economic growth (Miller and Uphadhay, 2000).

The model in Table 3 also allows for interactions between variables in the estimation process. A number of interactions were found to be important for productivity. The first important block of interactions dealt with openness as measured by the export-output ratio. In this block the interaction between the export-output ratio and market shares had a positive and significant impact on productivity. Also, within this block, the interaction between the exportoutput ratio and the real exchange rate has a negative and significant impact on total factor productivity. The other interaction in this group is between export-output ratios and inflation; this interaction had a negative and

${ }^{2}$ This results suggests the need to employ the effective industry nominal tariff rates themselves in empirical work. Fernandez (2003) reports a negative association between tariff rates and productivity. Productivity gains were associated with tariff declines. This again emphasises the need to employ tariff rates. 
significant association with manufacturing productivity performance.

The second vital block of interactions dealt with openness as measured by import penetration. As expected, the interaction between import penetration and market share impacted negatively on productivity. Within this block, interactions between the real exchange rate and inflation with import penetration had positive and significant effects on productivity. The interaction with the tariff measure impacted negatively on industrial productivity performance.

The third category concerns the interplay between machinery and equipment with other measures. In this group, it is only the relationship with the real exchange rate variable that had a negative and significant impact on manufacturing productivity. The fourth class of interactions captures the fundamental role of the rapport between other variables and intermediates on productivity. The significant associations in this case are between intermediates and market share as well as between intermediates and the real exchange rate. The latter had a negative effect while the former has a positive impact on productivity.

The final group of interactions deals with trade measures and levels of skill intensity in industrial sectors. The two associations are significant. It is, however, the interaction between import penetration and skill intensity that is found to connect positively and in a statistically significant way with productivity performance. This latter finding may be related to that in Miller and Uphadhay (2000) and indicates the fundamental role of trade in encouraging the use of skilled labour.

\section{(c) Dynamic Panel Results}

It is likely that an appropriate mechanism to capture the evolution of total factor productivity is to model it in a dynamic context. However, dynamic panel data regressions are characterised by two sources of persistence over time. The first is autocorrelation, due to the presence of a lagged dependent variable among the regressors. The second is the individual effects that characterise the heterogeneity among individuals. Inclusion of a lagged dependent variable makes the OLS estimator biased and inconsistent in estimating the coefficient of the dependent variable. Even the fixed effects estimator based on th^ within transformation will still be biased and inconsistent for a typical panel where $N$ is large and $T$ is fixed. The random effects GLS estimator is also biased in a dynamic panel data model. While the instrumental variable (IV) estimation method is consistent, it does not necessarily generate efficient estimates of model parameters. Ahn and Schmidt (1995) show that the IV estimator does not make use of all the available moment conditions and does not take into account the differenced structure of the residual disturbances.

Arrellano and Bond (1991) proposed a generalised method of moments (GMM) procedure to tackle the above problem. This procedure requires additional instruments that can be obtained by utilising the orthogonality conditions that exist between lagged values of the dependent variable and the disturbances. The generalised method of moments in Arellano and Bond (1991:288) employs differences, rather than levels, for instruments dated $t-2$ and earlier. In a nutshell, dynamic models employ transformations that use lagged endogenous variables as instruments using GMM estimators in the spirit of Arrellano and Bond (1991). Detailed implementation procedures are found in Arrellano and Bond (2001). In this section, we report the results of the one step GMM estimator. To reduce on the size of the estimated model, 
two things are implemented. First, the number of interactions provided in the model in Table 2 is reduced from five to only one. Second, only import pressure is employed as a direct measure of the impact of trade on manufacturing. Table 3 presents the results of the dynamic panel estimation using the first and second lags of explanatory variables as instruments.

Table 3. Dynamic panel estimation of total factor productivity determinants

Source: One step estimation results by the authors'

\begin{tabular}{|c|c|c|c|c|}
\hline Variable & Coefficient & St andard Error & t-value & t-probability \\
\hline Constant & 0.049 & 0.015 & 3.12 & 0.002 \\
\hline Change in total factor productivity- 1 & 0.976 & 0.064 & 15.4 & 0.000 \\
\hline Change in total factor productivity- 2 & -0.172 & 0.055 & -3.11 & 0.002 \\
\hline Change in import penetration ratio & 0.113 & 0.054 & 2.09 & 0.037 \\
\hline Change in import penetration ratio ${ }_{t-1}$ & -0.047 & 0.084 & -0.56 & 0.576 \\
\hline Change in import penetration ratio ${ }_{t-2}$ & -0.061 & 0.076 & -0.80 & 0.424 \\
\hline Change in tariff & 0.042 & 0.012 & 3.48 & 0.001 \\
\hline Change in tariff $\mathrm{t}-1_{1}$ & -0.037 & 0.014 & -2.62 & 0.009 \\
\hline Change in tariff $\mathrm{t}-2$ & -0.001 & 0.009 & -0.15 & 0.878 \\
\hline Change in mark-up ratio & 0.456 & 0.051 & 8.90 & 0.000 \\
\hline Change in mark- up ratio t- 1 & -0.346 & 0.077 & -4.50 & 0.000 \\
\hline Change in mark-up ratio $t-2$ & -0.013 & 0.064 & -0.21 & 0.835 \\
\hline Change in market share & -0.025 & 0.022 & -1.17 & 0.241 \\
\hline Change in market share $t-1$ & 0.032 & 0.016 & 1.99 & 0.047 \\
\hline Change in market share $t_{-2}$ & -0.025 & 0.014 & -1.73 & 0.085 \\
\hline Change in intermediate imports & -0.381 & 0.046 & -8.22 & 0.000 \\
\hline Change in intermediate imports $\mathrm{t}-1$ & 0.302 & 0.079 & 3.82 & 0.000 \\
\hline Change in intermediate imports $\mathrm{t}-1$ & 0.018 & 0.061 & 0.30 & 0.764 \\
\hline Change in real exchange rate & -0.103 & 0.031 & -3.31 & 0.001 \\
\hline Change in real exchange rate $t=1$ & 0.119 & 0.040 & 2.94 & 0.003 \\
\hline Change in real exchange rate & -0.024 & 0.012 & -1.98 & 0.048 \\
\hline Change in consumer price index & -0.009 & 0.004 & -2.39 & 0.017 \\
\hline Change in consumer price inde $\mathrm{x}_{\mathrm{t}-1}$ & -0.011 & 0.003 & -3.18 & 0.002 \\
\hline Change in consumer price index $\mathrm{t} 2$ & -0.003 & 0.001 & -2.31 & 0.021 \\
\hline Change in capacity utilisation & 0.154 & 0.121 & 1.27 & 0.204 \\
\hline Change in capacity utilisation $t=1$ & -0.186 & 0.085 & -2.20 & 0.028 \\
\hline Change in capacity utilisation $\mathrm{t} 2$ & 0.158 & 0.094 & 1.69 & 0.092 \\
\hline Import penetration tatio $X$ skill intensity & -0.072 & 0.017 & -4.16 & 0.000 \\
\hline Import penetration tatio $X$ skill intensityt-1 & 0.049 & 0.021 & 2.27 & 0.024 \\
\hline Import penetration ratio $X$ skill intensity $t 2$ & 0.021 & 0.025 & 0.83 & 0.405 \\
\hline Wald (Joint) & $\mathrm{Chi}^{2}(29)$ & $=4.81 \mathrm{e}+011[0.000]^{* *}$ & & \\
\hline Wald (Dummy) & $\mathrm{Chi}^{2}(19)$ & $=146.4[0.000]^{* *}$ & & \\
\hline Wald (Time) & $\mathrm{Chi}^{2}(19)$ & 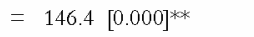 & & \\
\hline Sargan test & $\mathrm{Chi}^{2}(473)$ & 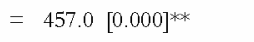 & & \\
\hline$A R$ (1) test & $\mathrm{N}(0,1)$ & $=-4.131[0.000]^{* * *}$ & & \\
\hline $\mathrm{AR}(2)$ test & $\mathrm{N}(0,1)$ & $=0.5156[0.606]$ & & \\
\hline
\end{tabular}

Note: Interaction terms are reduced to simplify the size of the model.

The results in Table 3 show an important association between openness measures and productivity. Competition in foreign markets is supposed to benefit industry productivity 
due to pressures for reduction in x-inefficiency and lower costs from the exposure to more advanced technologies. In the dynamic formulation, there is a statistically significant association between import pressure and productivity, with a level coefficient of 0.113 . This result is consistent with the arguments regarding the effect of globalisation in Hayter (2001). Faced with globalisation, manufacturing industries must lower costs to become more efficient in the face of increased import competition. Pedro et al (1993) argue that trade policies in South Africa should be designed to encourage firms to improve efficiency.

One measure of trade orientation is the level of sectoral tariffs. Empirical evidence has tended to indicate that high industrial tariffs affect productivity negatively. The results in this paper find that the measure of the impact of tariffs was significant but mixed. It is at the second lag that evidence of a reduction in tariffs impacted positively on productivity. The market share variable had only a weakly significant impact on productivity growth.

Increased competition should result in reduced market power for domestic firms and decrease their mark-ups. This is because mark-ups represent a manifestation of imperfect competition and capture the wedge between product prices over marginal costs. Though the overall coefficient on the mark-up ratio is positive, there is some weak evidence of a negative impact when lagged effects are introduced.

The increased imports of intermediate inputs are an important mechanism for industry level productivity gains. The data set has information on imported intermediate inputs and indicates that industries did differ in the degree to which production relied on imported inputs. The impact effect of intermediate imports on productivity was surprising. However, a positive association between intermediate imports and productivity is recovered in the second lag were the coefficient is 0.302 and is statistically significant.

The empirical implementation enables us to investigate the role of macroeconomic variables such as the real exchange rate and inflation changes on manufacturing productivity. The impact of the real exchange rate was statistically significant and correctly signed. The impact coefficient is -0.103 , suggesting that an overvalued rand has a significant negative effect on total factor productivity. In this framework, trade policies that move the real exchange rate towards its long-term purchasing parity level should associate with higher productivity because they stimulate industrial exports.

The coefficient of the impact of the inflation on productivity was -0.009 . It was both statistically significant and of the expected sign. This suggests that higher levels of inflation have a negative impact on the evolution of manufacturing productivity. Inflation is an indicator of variability in domestic prices, which can have a negative effect on the efficiency of price signals and could affect decisions to invest in new technology by firms because of increased uncertainty. Higher inflation has the potential to lower aggregate industrial output through its negative effect on total factor productivity.

In the dynamic formulation, there are mixed results regarding the impact of capacity utilisation in capturing the role of business cycles in affecting productivity. It is only the second lag, which is significant and suggests that productivity performance in manufacturing over the period investigated was negatively associated with the evolution of total factor productivity in manufacturing. This implies that the effect of trade and exchange rate liberalisation only imposes a gradual pressure on domestic manufacturing to adopt capacity utilisation towards more productive production techniques.

The dynamic model also looks at the impact of the interaction between import 
penetration and skill intensity levels in industries. The results are not clear-cut. Indeed a positive and significant effect comes in only at the second lag, indicating that while skilled labour and trade interact beneficially, it takes some time for the effects to run through the industries. This is consistent with the recommendation in Fallon and Pereira de Silva (1994) that prospects for success in South Africa will be improved considerably if skills are upgraded and reorientation towards exports is achieved.

The dynamic model also helps us to investigate the nature of persistence in manufacturing productivity. The first lag of total factor productivity enters the model with a positive coefficient of 0.98 , which is statistically significant. This suggests that past performance does affect in a fundamental way the future evolution of industrial productivity.

\section{CONCLUDING REMARKS}

An important association between trade measures and manufacturing productivity is revealed. Indeed, the benefits to productivity arise from pressures for a reduction in inefficiency and from lower costs associated with the exposure to more advanced technologies, intermediate inputs and machinery. Liberalisation of the external sector is good for competition and learning. Learning is available through increased access to world-class intermediate inputs and technology. The dynamic GMM results also indicate that the real exchange rate and inflation are some of the macroeconomic variables that interact with trade policy measures to affect industrial performance in a significant way.

In terms of future research directions, it would be interesting to examine the issue of productivity at a much lower classification level than the three-digit categorisation used here. Such research should employ plant level data sets that were generated by the manufacturing censuses of 1991, 1993 and 1996 and examine issues related to trade, industry concentration and efficiency in South Africa, as has been done in the Ivory Coast (Harrison, 1994).

\section{REFERENCES}

AHN, S.C AND SCHMIDT, P. (1995). Efficient estimation of models for dynamic panel data. Journal of Econometrics, 68:5-27. ARRELlanO, M., AND BOND, S.R. (2001). Panel data models, In Dornik A., et al (Eds), Econometric Modelling Using PCGIVE. London, UK: Timberlake Consultants Ltd.

_, AND BOND, S.R. (1991). Some tests of specification for panel data: Monte Carlo evidence and an application to employment equations. Review of Economic Studies 58: 277-297'.

BALTAGI, B.,(2002). Econometric analysis of panel data. New York, John Wiley and Sons.

BELLI, P, FINGER, M.J., AND BALLIVIAN, A. (1994). South Africa: A review of trade policies, World Bank Informal Discussion Papers on aspects of the South African Economy No. 7, The South African Department, The World Bank. DEININGER, K. (2003). Causes and consequences of civil strife: Micro-level evidence from Uganda. Oxford Economic Papers, 55: 579-607.

DERANIYAGALA, S AND FINE, B. (2000). New trade theory versus old trade policy: A continuing enigma. Journal of Political Economy, 96: 20-41.

DOORNIK, J.A., AND HENDRY,D.F. (2001). Econometric Modelling Using PcGive Vol. III. London: Timberlake Consultants Ltd.

DRLEMEIELR, M.H., IAROSSI, G., AND SOKOLOFF, K. (2002). Exports and manufacturing productivity in East Asia: A comparative analysis with firm level data. NBER Working PaperSS94.

FALLON, P AND L.A. LUIZ DE SILVA. (1994). South Africa : Economic performance and policies World Bank Informal Discussion Papers on Aspects of South African Economy No. 4, The South African Department, The World Bank.

FEDDERKE, J.W. (2001a). The structure of growth in the South African economy: Factor accumulation and total factor productivity growth 1970-1997. The South African Journal of Economics, 70: 611-646.

_ (2001b). The nature of South Africa's trade patterns by economic sector, and the extent of trade liberalisation

during the course of the 1990's. The South African Journal of Economics, 69:436-473.

FEENSTRA, R.C., MARKUSEN, J.R., AND ZELLE, W. (1992). Accounting for growth with new inputs: Theory and 
evidence" American Economic Review, 82:415-21.

FERNANDEZ, A.N. (2003). Trade policy, trade volumes and plant level productivity in Colombian manufacturing industries. The World Bank, 1818 Washington DC.

_ (2002). Trade policy, trade volumes and plant level productivity in Colombian manufacturing industries. Yale University Economic Growth Centre, Discussion Paper No. 847.

GROSSMAN, G., AND HELPMAN,E. (1991). Innovation and growth in the global economy. Cambridge: MIT Press. GUNNAR, J., AND SUBRAMANIAN, A. (2000). Dynamic gams from trade: Evidence from South Africa, International Monetary Fund. WP/00/45.

HARRISSON, A.E. (1996). Openness and growth: A time series, cross-country analysis for developing countries" journal of Development Economics, 48: 419-47.

HAYTER, S., REINECKE, G, AND TORRES, R. (1999). South Africa: Studies on the social dimensions of globalisation. Task force on country studies on globalisation, International Labour Office, Geneva.

KIM, E. (2000). Trade liberalisation and productivity growth in Korean manufacturing industries: Price protection, market power, and scale efficiency. Journal of "DevelopmentEconomics, 62: 55-83.

KRISHNA, P., AND MITRA, D. (1998). Trade liberalisation, market discipline and productivity growth: New evidence from India. Journal of Development Economics 56: 447-462.

LEE, J.W. (1995). Government interventions and productivity growth in Korean manufacturing industries. NBER Working Paper 5060.

LEVIN, A., LIN, C. F., AND CHU C. (2002). Unit root tests m panel data: Asymptotic and finite-sample properties, Journal of Econometrics, 108: 1-24.

LEVINSOHN, J., AND PETRIN, A. (2000). Estimating production functions using inputs to control for unobservables. NBER Working Paper No. 7819 Cambridge, MA.

LIU, L AND TyBOUT, J. (1996). Productivity growth in Chile and Colombia: The role of entry, exit and learning, In: Roberts, M and Tybout, J. (eds) Industrial evolution in developing countries. Oxford University Press.

MILLER, S.M AND UPADHAY ,M.P (2000). The effect of openness, trade orientation, and human capital on total factor productivity. Journal of Development Economics, 63: 399-423.

MUENDLER, M.A. (2002). Trade, technology, and productivity: A study of Brazilian manufacturers, 1986-1998. University of California, San Diego and CESifo.

NISHIMIZU, M. AND ROBINSON, S. (1983). Trade policies and productivity change in semi-industrialised countries. Development Research Paper, World Bank.

OLLEY, S.G AND PAKES, A. (1996). The dynamics of productivity in the telecommunications equipment industry. Econometrica ,64:1263-1297.

PAVCNIK, N. (2000). Trade liberalisation, exit, and productivity improvements: Evidence from Chilean plants, NBER Working Paper, W7852.

PETERSSON, L. (2002). Integration and mtra-industry trade adjustment in South Africa, Development South Africa, 19:239259.

Roberts, S. (2000). Understanding the effects of trade policy reform: The case of South Africa. The South African Journal of Economics . 68: 607-638

RODRICK, D. (1992). Conceptual issues in the design of trade policy for industrialisation. World Development, 20:309-320.

_ (1991). Closing the productivity gap: Does trade liberalisation really help"? In Hellemer, G. (Eds). Trade Policy,

Industrialisation and Development. Claredon Press. Oxford

_, AND RODRIQUEZ, F. (2001). Trade policy and economic growth: A sceptics guide to the cross-national evidence, In Bernanke, B and K Rogoff (eds) Macroeconomics Annual 2000. MIT Press for NBER. Cambridge, M.A.

SACHS, J. AND WARNER, A. (1995). Economic reform and the process of global integration. Brookings Papers on Economic

Activity, 1: 1-118.

SOUTH AFRICAN RESERVE BANK. (2003).Quarterly Bulletin, March 2003, (no. 227). Pretoria: South African Reserve Bank. Taybout J.R. (1992). Linking trade and productivity: New research directions. World Bank Economic Review, 6: 189-212.

_ , AND WESTBROOK, M.D. (1995). Trade liberalisation and the dimensions of efficiency change in Mexican manufacturing industries. Journal of International Economics, 39: 53-78.

_ , DE MELO, J., AND CARBO, V. (1991). The effects of trade reforms on scale and technical efficiency: New evidence

from Chile Journal of"International'Economics, 31: 231-250.

TIPS. (2001). The state of trade policy in South Africa, Trade and Industrial Policy Strategies, Rashad Cassim, Donald

Onyango, and Dirk Enst van Seventer

VAN BIESEBROEK, J. (2003). Exporting raises productivity in Sub-Saharan African manufacturing plants. NBER Working

PaperNo. 10020 